\title{
Methods of combating Acer negundo L. in specially protected natural areas
}

\author{
Anastasia A. Nikolaeva ${ }^{{ }^{*}}$, Elena V. Golosova ${ }^{1}$, and $O \lg a$ V. Shelepova ${ }^{1}$ \\ ${ }^{1}$ N.V. Tsitsin Main Botanical Garden of Russian Academy of Sciences, 127276, Moscow, Russian \\ Federation
}

\begin{abstract}
The possibility of using chemical and mechanical methods to control the undesirable growth of the invasive species Acer negundo L. at the expositions of the Main Botanical Garden of the Russian Academy of Sciences, which has the status of a specially protected natural area, was studied. It was found that treatment of freshly cut stumps of A. negundo with glyphosphate in concentration of $7.2 \mathrm{~g} / 1$ causes death of $65 \%$ of plants. In the rest of the specimens of A. negundo from this option the amount of growing epicormic sprouts decreased by 5.2 times in comparison with the usual cutting (control).
\end{abstract}

\section{Introduction}

The Acer negundo L. is widely used in urban greening, in creating protective strips along highways and in agriculture, suburban forests, often along river banks. In the European part of Russia, the species has been given the status of an invasive species, with which it is recommended that control measures be taken [1]. At present, A. negundo is regarded as a fast-growing species, the use of which is limited to a certain period of time and should be removed from the main plantations [2,3]. However, no effective methods have been proposed for the removal of this species from the plantations. Cutting (trunk cutting) of plants is a necessary but not sufficient measure, as a large number of shoots are formed on the stump from the sleeping buds $[4,5]$. Mechanical methods of struggle against vegetative renewal are labor-intensive and ineffective [6]. Chemical method of treatment (application of arboricides) of shoots reduces labor costs in 5 times, and the cost of work in 2.2 times [7].

The first experiments with $A$. negundo young growth using arboricides (Tornado preparation $50 \%$ ) showed the decrease of shoots growth in a month after treatment $[4$, 5]. The task of our studies was to estimate the growing epicormic sprouts of A. negundo in using various chemical treatments that are allowed in specially protected natural areas.

\section{Materials and Methods}

\footnotetext{
${ }^{*}$ Corresponding author: nikolaeva.gbs@gmail.com
} 
The study was conducted at the MBS RAS expositions (a specially protected natural area), the first 3 specimens of $A$. negundo were planted in the "garden of coastal plants" in 1963. During 56 years of introduction the population has increased tenfold - 67 specimens of different ages with a trunk diameter from 4 to $56 \mathrm{~cm}$ (Fig. 1). The plants have penetrated into the nearest natural forest area and form solid thickets with no herbaceous communities under their canopy.

In the course of the experiment 67 specimens - 46 single-barrow and 21 multi-barrow, with stump diameters from $4 \mathrm{~cm}$ to $56 \mathrm{~cm}$ - were removed. Variants of experience: control (stump saws without treatment); variant 1 - treatment of freshly cut stump saws with glyphosphate solution (concentration $7.2 \mathrm{~g} / \mathrm{l}$ ); variant 2 - treatment of stump saws one month after removal of the plant with glyphosphate solution (concentration $7.2 \mathrm{~g} / 1$ ); variant 3 - treatment of the freshly cut sawn stump with ammonium nitrate ( $45 \mathrm{~g}$ per 1 sawn stump) with the following covering with the moistureproofing material for 3 months; variant 4 treatment of the fresh sawn stump with ammonium nitrate ( $45 \mathrm{~g}$ per 1 sawn stump), covering with the moistureproofing material for 1 month and the following treatment of the stump with the glyphosphate solution (concentration $7.2 \mathrm{~g} / \mathrm{l}$ ).

For the next growing year, the number of the number of growing epicormic sprouts in each variant of experience was recorded and the type of epicormic sprouts was assessed. Average values of the studied indicators $(\mathrm{M})$, standard errors of averages $( \pm$ SEM) and confidence interval at $95 \%$ confidence level $\left(\mathrm{t}_{0,05} \pm \mathrm{SEM}\right)$ were determined. Differences between variants were considered reliable at $\mathrm{p} \leq 0.05$.

\section{Results and Discussion}

During the vegetation period, the growth of $A$. negundo in different variants of experience was of different intensity.

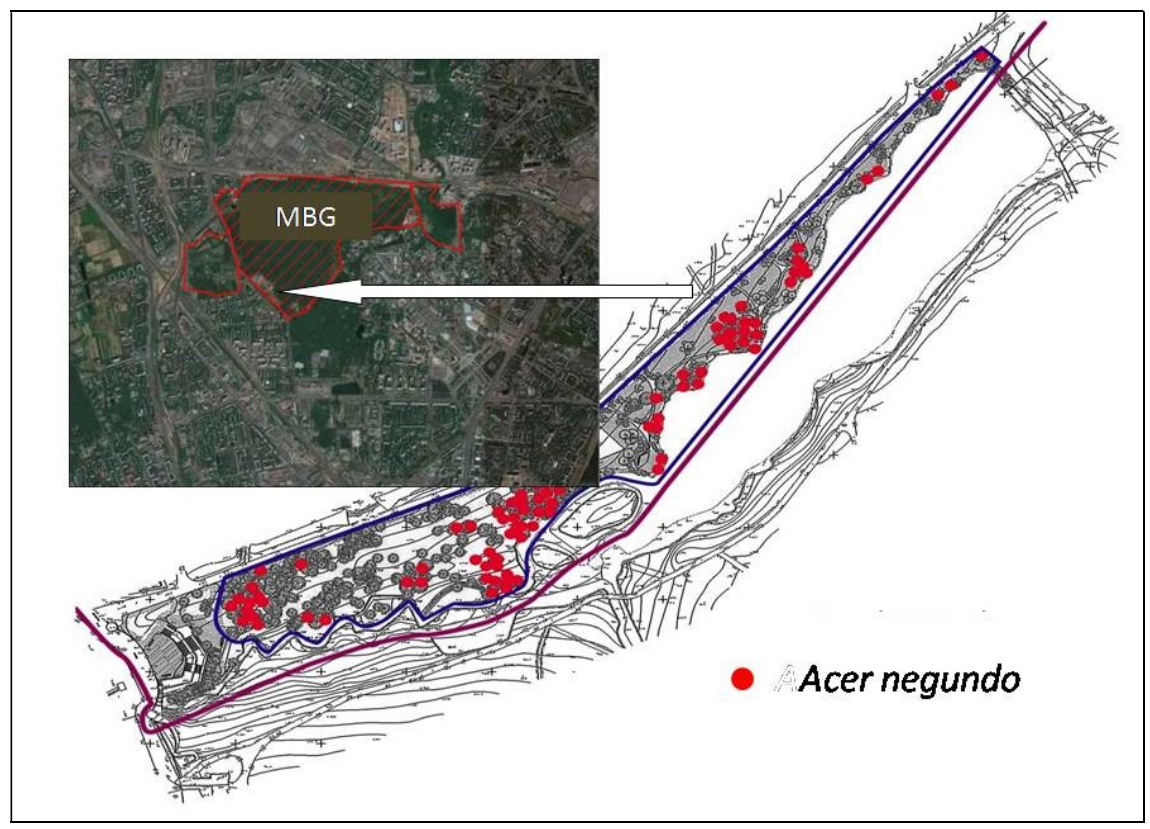

Fig. 1. Experiment area

The cut down trees at the control gave abundant shoots, its height reached $1.5 \mathrm{~m}$. It was green, with no signs of damage or oppression (Fig. 2). Both stumpy shoots (to a greater 
extent) and root progeny were recorded. Maximum number of waking buds was 130 pcs/stump. The bark on the stumps is tightly bedded to the wood, not peeling off, no mushroom bodies found.

Variant 1 - as a result of treatment of freshly sawn stumps with $A$. negundo glyphosphate $65 \%$ of specimens of this variant died (Fig. 2, 3). It is known from the literature that the use of glyphosphate (the active substance of roundup) helps to prevent the appearance of root progeny and stumpy growth of deciduous rocks and manifests itself in suppression of vitality of cambium cells with their subsequent death [8]. A similar pattern was observed in this variant of experience - only $35 \%$ of specimens registered the renewal of root progeny, and stumpy shoots were not formed. All stumps of the bark peeled off, and the presence of fruit bodies of fungi was recorded on some specimens..
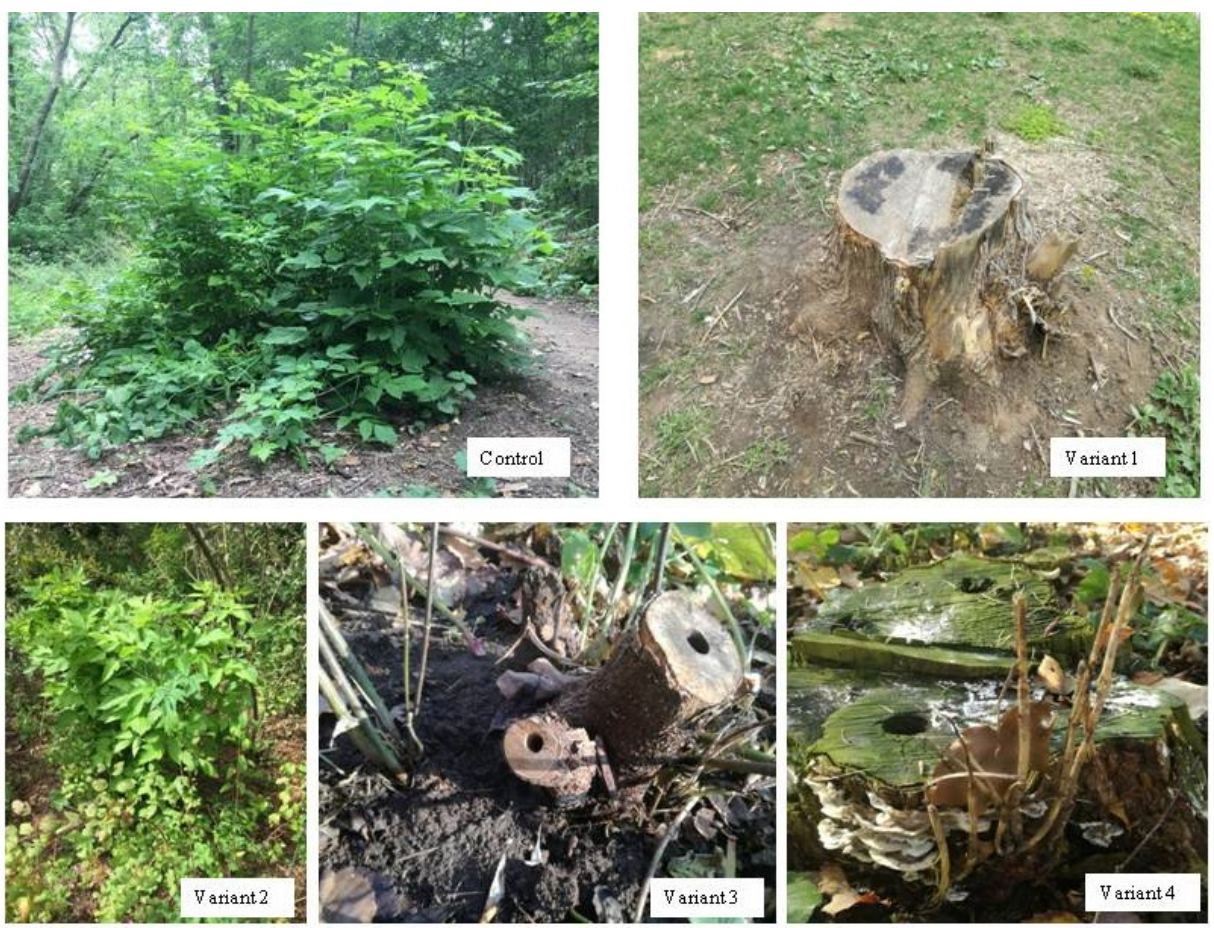

Fig. 2. The result of various chemical treatments of $A$. negundo in the next growing year after removal of the stem.

Variant 2 - shoots regeneration is noted for all specimens of $A$. negundo (Fig. 2). Stumpy shoots (from appendage buds) were formed, no root progeny was recorded. The bark on stumps flaked fragmentarily, on some stumps the presence of fruit bodies of tratovic mushrooms was noted.

Variant 3 - regrowth was not recorded in $20 \%$ of trees of this variant (Fig. 2, 3). On the other stumps there was a growth of shoots: $33 \%$ of the group gave stump growth, $47 \%$ - only root offspring. The bark on the felled trunks peeled off, there are fruit bodies of mushrooms, the wood is destroyed.

Variant 4 - in $17 \%$ of specimens of this version of the growth of $A$. negundo not recorded. The rest have grown stumpy (41\%) shoots and root (42\%) offspring. The bark was peeling off, and fruit bodies of fungi were found everywhere. 


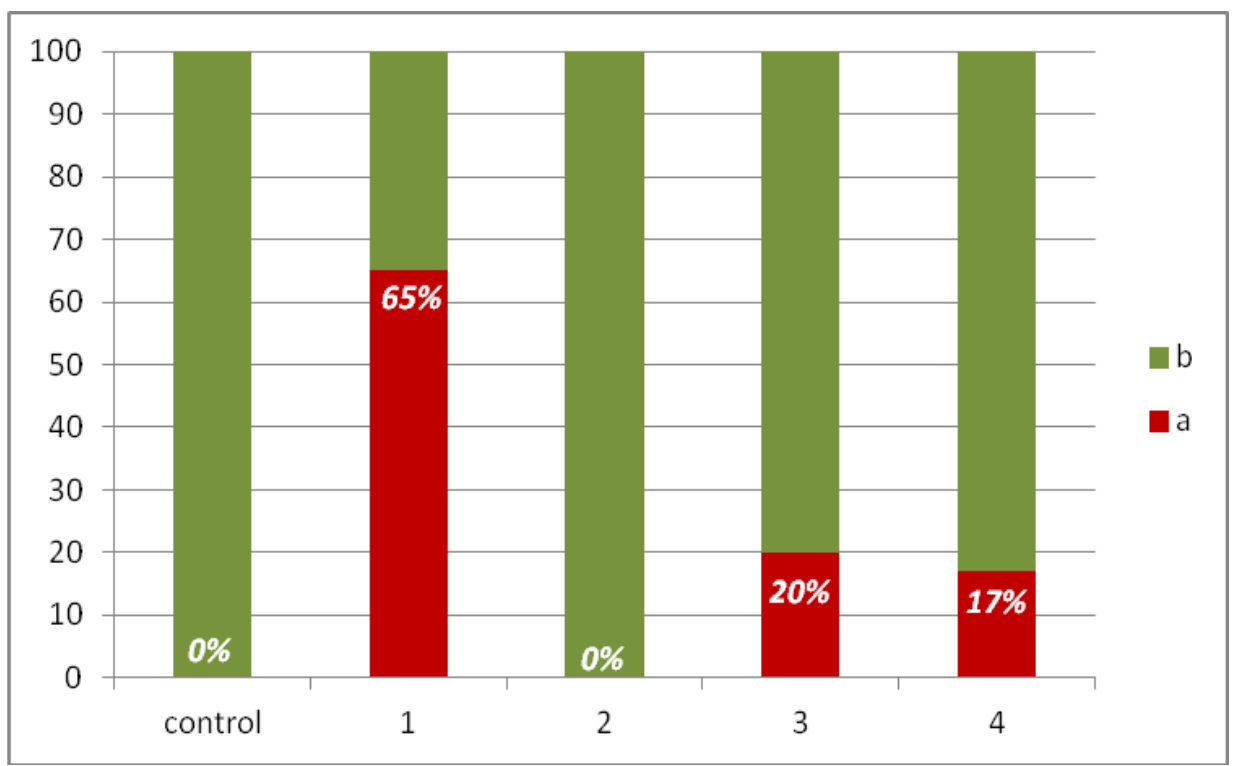

Fig. 3. Evaluation of effectiveness of different methods of control of $A$. negundo invasive: a - number of dead plants; $\mathrm{b}$ - number of $A$. negundo specimens with growing epicormic sprouts; 1 - mechanical cutting of $A$. negundo, 1 - variant 1;2 - variant 2; 3 - variant 3; 4 - variant 4.

In the surviving plants of $A$. negundo, the number of growing shoots and their height were taken into account (Table). It was found out that the best result of shoot suppression is characteristic for variant 1: the average number of shoots is 5.2 times less than control, and the height of shoots is 2 times lower in comparison with control, while the same indicators for other variants of treatment are only 1.2-2.1 and 1.6 times lower than control.

Table. Estimation of stumps viability $A$. negundo and recording of growing epicormic sprouts by variants of experience.

\begin{tabular}{|c|c|c|c|c|}
\hline \multirow{2}{*}{$\begin{array}{l}\text { Variants of } \\
\text { experience }\end{array}$} & \multicolumn{2}{|c|}{$\begin{array}{l}\text { Amount of stumps by variants of } \\
\text { experience, pcs. }\end{array}$} & \multirow{2}{*}{$\begin{array}{l}\text { Amount of shoots } \\
\text { of stumps, } \\
\text { pcs./stump }\end{array}$} & \multirow[t]{2}{*}{$\begin{array}{l}\text { Average height of } \\
\text { shoots, } \mathrm{cm}\end{array}$} \\
\hline & In total & $\begin{array}{l}\text { With growing } \\
\text { shoots }\end{array}$ & & \\
\hline Control & 10 & 10 & $62 \pm 5$ & $132 \pm 15$ \\
\hline Variant 1 & 20 & 7 & $12 \pm 1$ & $65 \pm 10$ \\
\hline Variant 2 & 10 & 10 & $30 \pm 4$ & $83 \pm 13$ \\
\hline Variant 3 & 15 & 12 & $44 \pm 5$ & $84 \pm 11$ \\
\hline Variant 4 & 12 & 10 & $51 \pm 4$ & $81 \pm 15$ \\
\hline
\end{tabular}

The degree of wood destruction differed significantly in terms of experience options. The control samples of bark did not peel off, the wood on a sawn was firm, the similar situation was fixed in variant 2 , in variant 1 the bark peeled off, but the wood remained firm. The greatest degree of stump destruction was observed in variants 3 and 4 - bark flakes, wood on the saw is soft.

Thus, the chemical method of combating A. negundo stump growth and root progeny on the expositions of the Main Botanical Garden of the Russian Academy of Sciences (specially protected area) with the use of glyphosphate $(7.2 \mathrm{~g} / \mathrm{l})$ was very effective $-65 \%$ of specimens did not show stump growth and root progeny growth. 
Besides, the method demonstrated high ecological safety (herbicide does not get on the living ground cover, which excludes poisoning of animals); the preparation destructs quickly (2-4 weeks) [8]; low environmental impact [9]; safe for humans; easy to use; independent from weather conditions. The results of the conducted experience allow recommending glyphosphate for treatment of freshly cut stumps of A. negundo in specially protected areas as one of the most effective and ecologically safe ways to control this invasive species.

The research was carried out within the framework of the State Task of N.V.Tsitsin MBG RAS "Biological diversity of natural and cultural flora: fundamental and applied issues of study and conservationl", state registration number 118021490111-5.

\section{References}

1. Yu.K.Vinogradova, S.Ed. Mayorov, L.V. Horun, Black Book of Flora of Central Russia (Geos, Moscow, 2010). In Russ.

2. M.V. Kostina, O.I.Yasinskaya, N.S.Barabanshchikova, F.A. Orlyuk Russian Journal of Biological Invasions, 8, $72-78$ (2015). In Russ.

3. P.U. Yanbaev, Agricultural Russia, 6, 51-52 (2009). In Russ.

4. A.P. Kling, A.A. Gayvas, V.N. Kumpan, Fruit and berry growing in Russia, 39, 105 109 (2014). In Russ.

5. V.R. Gofman, A.P. Kling, Student Scientific Forum, in Proceedings of the VII International Student Scientific Conference, 15-31 march 2015, Moscow, Russia (2015) In Russ.

6. A.N. Martunov, N.V. Belyaeva, O.I. Grigoryeva, Modern problems of forestation. Chemical and integrated forest care (GLTA, Saint Petersburg, 2008). In Russ.

7. V.S. Vavin, A.V. Popov, International Scien. And Resear. J., 7, 71-72 (2014). In Russ.

8. V.V. Nosikov, A.V. Urenja, A.P. Mayseenok, Proceedings of BSTU. Series 1: Forestry, Nature Management, and Renewable Resources Processing, 1, 119-123 (2016). In Russ.

9. V.S. Vavin, A.V. Popov, International Scien. And Resear. J., 12, 88-91 (2017). In Russ. 